\title{
Correlation with Redox Potentials and Inhibitory Effects on Epstein-Barr Virus Activation of Azaanthraquinones
}

\author{
Junko Koyama, ${ }^{*, a}$ Izumi Morita, ${ }^{a}$ Kiyoshi Tagahara, ${ }^{a}$ Toshiyuki Osakai, ${ }^{b}$ Hiroki Hotta, ${ }^{b}$ \\ Mou Xiao Yang, ${ }^{c}$ Teruo MukainaKa, ${ }^{c}$ Hoyoku Nishino, ${ }^{c}$ and Harukuni ToKudA ${ }^{c}$ \\ Kobe Pharmaceutical University, ${ }^{a}$ Higashinada, Kobe 658-8558, Japan, Department of Chemistry, Faculty of Science, \\ Kobe University, ${ }^{b}$ Nada, Kobe 657-8501, Japan, and Department of Biochemistry, Kyoto Prefectural University of \\ Medicine, ${ }^{c}$ Kyoto 602-8566, Japan. $\quad$ Received March 26, 2001; accepted May 25, 2001
}

The redox potentials have been determined for nine azaanthraquinones in phosphate buffer at pH 7.2 by means of cyclic voltammetry. A definite correlation has been found between the redox potentials and the inhibitory effects of the azaanthraquinones on Epstein-Barr virus early antigen (EBV-EA) activation. It has further been shown that the correlation can be made better by introducing an electronic property, i.e., the atomic charge at $\mathrm{O}^{11}$ as an additional parameter.

Key words azaanthraquinone; Epstein-Barr virus activation; redox potential; cyclic voltammetry; anti-tumor promoting effect

Recently, several natural products (flavonoids, steroids, triterpenoids, quassinoids) have been studied for their inhibitory effects on 12-O-tetradecanoylphorbol-13-acetate (TPA)induced Epstein-Barr virus early antigen (EBV-EA) activation and, thus, as potential anti-tumor promoting agents. ${ }^{1-4)}$ In a continuation of our work on the constituents of plants, we have also found inhibitory activities of anthraquinones on EBV-EA activation, and have studied their connections with electronic properties of the anthraquinones. ${ }^{5,6)}$ One class of antineoplastic agents contain a planar chromophore that is inserted between two base pairs in the DNA helix, causing a local untwisting of the helix resulting in miscoding and possible cell death ${ }^{7}$ _- for example, Mitoxantrone, which contains a planar anthraquinone skeleton, is a clinically useful antineoplastic agent. ${ }^{8)}$

Many anthraquinones are known to demonstrate various physiological activities, and some of their biological effects have been thought to be in intimate correlation with the redox property of the anthraquinone moiety. ${ }^{9)}$ In studies of the quantitative structure-activity relationships for drugs, the redox potential is one of the most important parameters to determine the physiological activities of drugs. We employed cyclic voltammetry to determine standard redox potentials of nine anthraquinones at a physiological $\mathrm{pH}$ (7.2), and then found a definite correlation between the standard redox potential and the inhibitory effect $\left(\log \mathrm{IC}_{50}\right)$ on EBV-EA activation. ${ }^{10)}$ In this study, we report the redox potentials of nine azaanthraquinones and the structure-activity relationship between the inhibitory effects of azaanthraquinones and the redox potentials. Further, we have calculated some electronic properties of the azaanthraquinones by the PM3 method using the CAChe MOPAC program. ${ }^{11)}$ It has been revealed that the atomic charge at $\mathrm{O}^{11}$ may be used as another useful parameter to characterize the inhibitory effect on EBV-EA activation.

\section{Experimental}

Reagents and Materials Benzo[g]quinoline-5,10-dione (1) and 6-hydroxybenzo[g]quinoline-5,10-dione (2) were synthesized from 5,8-quinolone and cyclohexadiene derivatives.

Benzo[g]quinoline-5,10-dione (1): IR $\left(\mathrm{CHCl}_{3}\right) \mathrm{cm}^{-1}$ : 1688, 1667, 1575. ${ }^{1} \mathrm{H}-\mathrm{NMR}\left(\mathrm{CDCl}_{3}\right) \delta: 7.77(1 \mathrm{H}, \mathrm{m}, 3-\mathrm{H}), 7.87(2 \mathrm{H}, \mathrm{m}, 6,7-\mathrm{H}), 8.36(2 \mathrm{H}, \mathrm{m}$, $5,6-\mathrm{H}), 8.65(1 \mathrm{H}, \mathrm{dd}, J=8,1.5 \mathrm{~Hz}, 4-\mathrm{H}), 9.13(1 \mathrm{H}, \mathrm{dd}, J=4.5,1.5 \mathrm{~Hz}, 2-\mathrm{H})$.
High resolution (HR)-MS m/z: $209.0489\left(\mathrm{M}^{+}\right.$, Calcd for $\mathrm{C}_{13} \mathrm{H}_{7} \mathrm{NO}_{2}$ : 209.0476).

6-hydroxybenzo[g]quinoline-5,10-dione (2): IR $\left(\mathrm{CHCl}_{3}\right) \mathrm{cm}^{-1}$ : 1682, 1633, 1579. ${ }^{1} \mathrm{H}-\mathrm{NMR}\left(\mathrm{CDCl}_{3}\right) \delta: 7.25(1 \mathrm{H}, \mathrm{d}, J=8 \mathrm{~Hz}, 6-\mathrm{H}), 7.78(1 \mathrm{H}, \mathrm{dd}$, $J=8,5 \mathrm{~Hz} 3-\mathrm{H}), 7.83(1 \mathrm{H}, \mathrm{d}, J=8 \mathrm{~Hz}, 7-\mathrm{H}), 8.03(1 \mathrm{H}, \mathrm{d}, J=8 \mathrm{~Hz}, 8-\mathrm{H}), 8.68$ $(1 \mathrm{H}, \mathrm{d}, J=8 \mathrm{~Hz}, 4-\mathrm{H}), 9.16(1 \mathrm{H}, \mathrm{d}, J=5 \mathrm{~Hz}, 2-\mathrm{H}), 13.02(1 \mathrm{H}, \mathrm{s}, \mathrm{OH}) . \mathrm{HR}-$ MS $m / z: 225.0441\left(\mathrm{M}^{+}\right.$, Calcd for $\left.\mathrm{C}_{13} \mathrm{H}_{7} \mathrm{NO}_{3}: 225.0426\right)$.

6,9-Dihydroxy-2-methylbenzo[g]quinoline-5,10-dione (3), 3-methylbenzo[g]quinoline-5,10-dione (4), 9-hydroxy-3-methylbenzo[g]quinoline-5,10-dione (5), 6,9-dihydroxy-3-methylbenzo[g]quinoline-5,10-dione (6), 4-methylbenzo[g]quinoline-5,10-dione (7), 9-hydroxy-4-methylbenzo[g]quinoline5,10-dione (8), and 6,9-dihydroxy-4-methylbenzo[g]quinoline-5,10-dione (9) were synthesized from naphthoquinones using the Diels-Alder reaction. ${ }^{5)}$ The tissue culture reagents, TPA, $n$-butyric acid and other reagents, were from Nacalai Tesque. EBV-genome-carrying lymphoblastoid cells (Raji cells derived from Burkitt's lymphoma) were cultured in RPMI 1640 medium (Nissui), as described elsewhere. ${ }^{12}$ Spontaneous activation of EBVEA in our subline of Raji cells was less than $0.1 \%$.

Procedure of EBV-EA Activation The inhibition of EBV-EA activation was assayed using Raji cells (virus non-producer), which were cultivated in $8 \%$ fetal bovine serum (FBS) RPMI 1640 medium. The indicator cells (Raji) $\left(1 \times 10^{6} \mathrm{ml}\right)$ were incubated at $37^{\circ} \mathrm{C}$ for $48 \mathrm{~h}$ in $1 \mathrm{ml}$ of the medium containing $n$-butyric acid ( $4 \mathrm{~mm}$, inducer) $2 \mu \mathrm{l}$ of TPA $(20 \mathrm{ng} / \mathrm{ml}$ in dimethyl sulforide (DMSO)), and a known amount of test compound of DMSO. Smears were made from the cell suspension. The activated cells were stained by

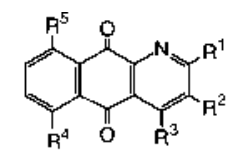

\begin{tabular}{|c|c|c|c|c|c|}
\hline Compd. & $\mathrm{F}^{\prime}$ & $\mathrm{k}^{2}$ & $\mathbf{R}^{\prime}$ & $\mathrm{K}^{1}$ & $\mathrm{k}^{3}$ \\
\hline 1 & $H$ & $H$ & $\mathrm{H}$ & $\mathbf{H}$ & $\mathbf{H}$ \\
\hline 2 & $\mathrm{H}$ & $H$ & $\mathrm{H}$ & $\mathrm{OH}$ & H \\
\hline 3 & $\mathrm{CH}_{3}$ & $H$ & $\mathrm{H}$ & OH & $\mathrm{OH}$ \\
\hline 4 & $\mathrm{H}$ & $\mathrm{CH}_{3}$ & $\mathrm{H}$ & $\mathrm{H}$ & $\mathbf{H}$ \\
\hline 5 & $\mathrm{H}$ & $\mathrm{CH}_{3}$ & $\mathrm{H}$ & $\mathbf{H}$ & $\mathrm{OH}$ \\
\hline fi & $\mathrm{H}$ & $\mathrm{CH}_{3}$ & $\mathrm{H}$ & $\mathrm{OH}$ & $\mathrm{OH}$ \\
\hline 7 & $H$ & H & $\mathrm{CH}_{3}$ & $\mathbf{H}$ & $\mathrm{H}$ \\
\hline 8 & $H$ & H & $\mathrm{CH}_{\mathrm{a}}$ & H & $\mathrm{OH}$ \\
\hline y & $\mathrm{H}$ & $H$ & $\mathrm{CH}_{3}$ & $\mathrm{OH}$ & $\mathrm{OH}$ \\
\hline
\end{tabular}

Chart 1 
high-titer EBV-EA positive sera from nasopharyngeal carcinoma (NPC) patients and detected by a conventional indirect immunofluorescence technique. $^{13)}$

In each assay, at least 500 cells were counted, and the experiments were repeated three times. The average EA induction was compared with that of positive control experiments with $n$-butyric acid ( $4 \mathrm{~mm}$ ) plus TPA ( $32 \mathrm{pmol})$, in which EA induction was ordinarily around $40 \%$. In this screening method, the cell viability required for the judgment of inhibitory effects was more than $60 \%{ }^{14)}$

Electrochemical Measurements Cyclic voltammetric measurements were performed in a similar manner as reported previously. ${ }^{10)}$ A conventional three-electrode system was employed with a plastic-formed-carbon (PFC) working electrode (BAS, PFCE-3, surface area $=0.071 \mathrm{~cm}^{2}$ ), a platinum counter electrode, and an $\mathrm{Ag} / \mathrm{AgCl}$ (saturated $\mathrm{KCl}$ ) reference electrode. For each voltammogram record, pretreatment of the working electrode was carried out as described previously. ${ }^{10)}$ Test solutions were degassed with prepurified $\mathrm{N}_{2}$ gas prior to the voltammetric measurements. The electrolytic cell was water-jacketed to maintain the temperature at $25 \pm 0.1^{\circ} \mathrm{C}$.

\section{Results and Discussion}

Nine azaanthraquinones have been tested for inhibitory activities using a short-term in vitro assay of the EBV-EA activation induced by TPA in Raji cells. Their inhibitory effects on activation of the EA and the values of $\log \mathrm{IC}_{50}$ are shown in Table 1.

Figure 1 shows a typical cyclic voltammogram which was recorded in the presence of $0.1 \mathrm{~mm}$ azaanthraquinone (1) in $0.1 \mathrm{M}$ phosphate buffer $(\mathrm{pH} 7.2)$. The voltage scan rate was usually set on $100 \mathrm{mV} \mathrm{s}^{-1}$. As seen in the Figure, a well-developed, reversible wave with cathodic and anodic peaks was obtained. The cathodic peak is ascribed to the two-electron reduction of azaanthraquinone, whereas the anodic peak is due to its reoxidation. The peak separation, i.e., the difference between the cathodic and anodic peak potentials $\left(\Delta E_{\mathrm{p}}=E_{\mathrm{pa}}-E_{\mathrm{pc}}\right)$ is $28 \mathrm{mV}$, being close to the theoretical value of $c a .30 \mathrm{mV}$ for a two-electron reversible wave. ${ }^{15)}$ For other azaanthraquinones, however, quasi-reversible waves with comparatively large $\Delta E_{\mathrm{p}}$-values $(33-77 \mathrm{mV})$ were obtained (see Table 2). Even for these quasi-reversible waves, the midpoint potential $\left[E_{\text {mid }}=\left(E_{\mathrm{pc}}+E_{\mathrm{pa}}\right) / 2\right]$ may be adequately assumed to be the apparent standard redox potential $E^{\circ}$ under given conditions. It is generally known that the redox potentials of quinones are affected by $\mathrm{pH}$. In this study, however, the values of $E^{\circ}$ for the azaanthraquinones were determined at a physiological $\mathrm{pH}$ (7.2), and their connection with the anti-tumor promoting effect was examined.

In Fig. 2, the values of $\log \mathrm{IC}_{50}$ are plotted against $E^{\circ}$ (in $\mathrm{V})$. The plot shows that there is an apparent correlation between the values of $\log \mathrm{IC}_{50}$ and $E^{\circ}$. The $\log \mathrm{IC}_{50}$ has been found to be represented by a regression line:

$$
\begin{aligned}
& \log \mathrm{IC}_{50}=4.308+3.941 E^{\circ} \\
& n=9, \quad s=0.189, \quad r=0.800
\end{aligned}
$$

where $n, s$, and $r$ are, respectively, the number of test compounds, the standard deviation, and the correlation coefficient. Thus it has been revealed that the redox potential at $\mathrm{pH}$ 7.2 is an important parameter determining the EBV-EA activation of the azaanthraquinones. The more negative the $E^{\circ}$ of the azaanthraquinones are, the stronger the anti-tumor promoting effect.

Furthermore, we examined the correlation of $\log \mathrm{IC}_{50}$ with the electronic properties of the azaanthraquinones. Table 3 shows the electronic properties, including the total energy, solvent accessible surface area, and the charges at the $\mathrm{C}^{5}$,

\begin{tabular}{|c|c|c|c|c|c|}
\hline \multicolumn{6}{|c|}{$\%$ to control ( $\%$ viability) } \\
\hline \multirow{2}{*}{ Compound } & \multicolumn{4}{|c|}{ Concentration (mol ratio/32 pmol TPA) } & \multirow{2}{*}{$\left.\log \mathrm{IC}_{50}{ }^{a}\right)$} \\
\hline & 1000 & 500 & 100 & 10 & \\
\hline 1 & 52.5 & 84.7 & 100 & 100 & 3.04 \\
\hline 2 & 58.3 & 77.3 & 92.5 & 100 & 3.07 \\
\hline 3 & $0(10)$ & $13.5(60)$ & $43.8(>80)$ & 86 & 2.41 \\
\hline 4 & $0(>70)$ & $48.7(>80)$ & 76.5 & 100 & 2.67 \\
\hline 5 & $0(30)$ & $15.8(>80)$ & 72.4 & 100 & 2.58 \\
\hline 6 & $6.1(40)$ & $16.8(50)$ & $82.6(>80)$ & 100 & 2.62 \\
\hline 7 & $40.6(>70)$ & $48.7(>80)$ & 77.5 & 100 & 2.82 \\
\hline 8 & $0(40)$ & $15.4(60)$ & $67.4(>80)$ & 89.1 & 2.52 \\
\hline 9 & $10.4(60)$ & $23.1(60)$ & $52.1(>80)$ & 88.6 & 2.52 \\
\hline
\end{tabular}

Table 1. Inhibitory Effects of Azaanthraquinones on EBV-EA Activation

a) The compound concentration (mol) of $50 \%$ inhibition against a positive control $(100 \%)$ was defined as $\mathrm{IC}_{50}$.

Table 2. $E_{\mathrm{pa}}, E_{\mathrm{pc}}, E^{\circ}$ Values of Azaanthraquinones

\begin{tabular}{lllll}
\hline \hline & $E_{\mathrm{pa}}(\mathrm{V})$ & $E_{\mathrm{pc}}(\mathrm{V})$ & $E^{\circ a)}(\mathrm{V})$ & $\Delta E_{\mathrm{p}}(\mathrm{mV})$ \\
\hline $\mathbf{1}$ & -0.352 & -0.380 & -0.366 & 28 \\
$\mathbf{2}$ & -0.304 & -0.375 & -0.339 & 71 \\
$\mathbf{3}$ & -0.424 & -0.468 & -0.446 & 44 \\
$\mathbf{4}$ & -0.353 & -0.399 & -0.376 & 46 \\
$\mathbf{5}$ & -0.389 & -0.437 & -0.413 & 48 \\
$\mathbf{6}$ & -0.449 & -0.511 & -0.480 & 62 \\
$\mathbf{7}$ & -0.365 & -0.402 & -0.384 & 37 \\
$\mathbf{8}$ & -0.379 & -0.456 & -0.418 & 77 \\
$\mathbf{9}$ & -0.447 & -0.487 & -0.467 & 40 \\
\hline
\end{tabular}

a) Assumed to be $E_{\text {mid }}$.

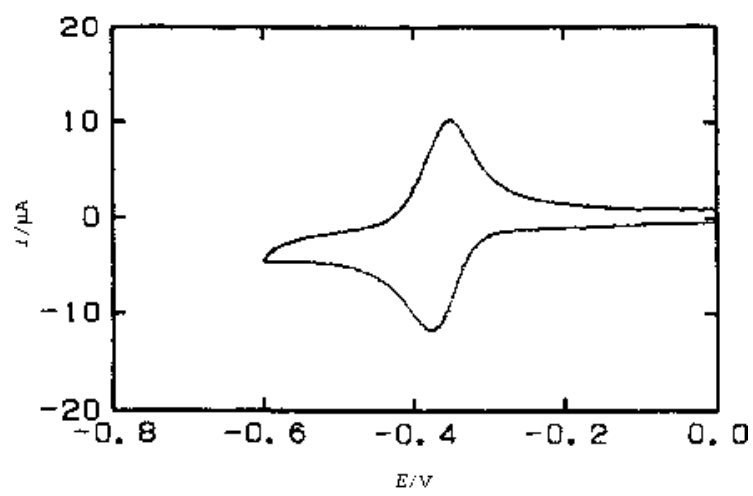

Fig. 1. Cyclic Voltammogram of Azaanthraquinone (1) at a PFC Electrode in $0.1 \mathrm{M}$ Phosphate Buffer ( $\mathrm{pH} 7.2)$

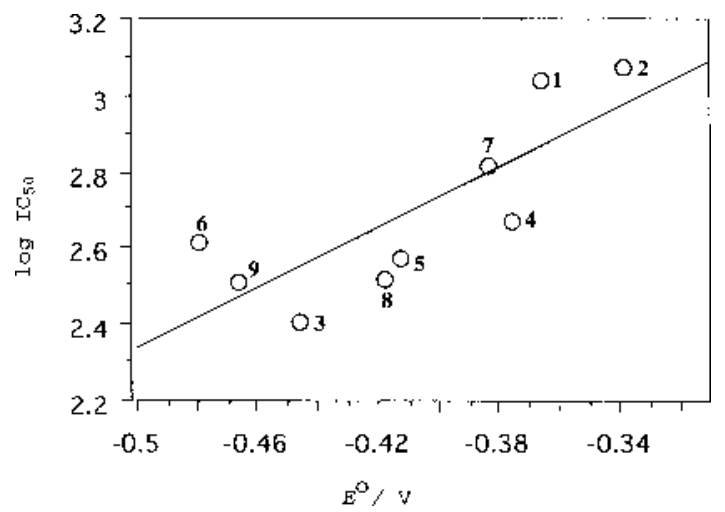

Fig. 2. Regression Plot of $\log \mathrm{IC}_{50}$ and Standard Redox Potential at $\mathrm{pH} 7.2$ 
Table 3. Electronic Properties of Azaanthraquinones

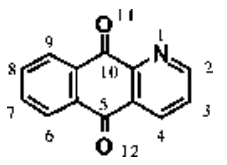

\begin{tabular}{|c|c|c|c|c|c|c|}
\hline & Total energy & Solvent accessible surface area & Charge of $\mathrm{C}^{5}$ & Charge of $\mathrm{C}^{10}$ & Charge of $\mathrm{O}^{11}$ & Charge of $\mathrm{O}^{12}$ \\
\hline 1 & -109.48 & 99.86 & 0.376 & 0.359 & -0.266 & -0.309 \\
\hline 2 & -121.72 & 102.48 & 0.410 & 0.354 & -0.261 & -0.358 \\
\hline 3 & -141.15 & 111.57 & 0.407 & 0.390 & -0.314 & -0.358 \\
\hline 4 & -116.67 & 106.53 & 0.376 & 0.361 & -0.268 & -0.310 \\
\hline 5 & -128.91 & 108.50 & 0.371 & 0.396 & -0.317 & -0.305 \\
\hline 6 & -141.15 & 111.52 & 0.405 & 0.392 & -0.314 & -0.356 \\
\hline 7 & -116.66 & 104.61 & 0.379 & 0.357 & -0.266 & -0.315 \\
\hline 8 & -121.72 & 102.32 & 0.371 & 0.396 & -0.313 & -0.299 \\
\hline 9 & -141.15 & 109.02 & 0.410 & 0.388 & -0.312 & -0.362 \\
\hline$r^{a)}\left(\right.$ with $\left.\mathrm{IC}_{50}\right)$ & 0.703 & 0.739 & 0.07 & 0.842 & 0.855 & 0.106 \\
\hline
\end{tabular}

a) $r$, correlation coefficient.

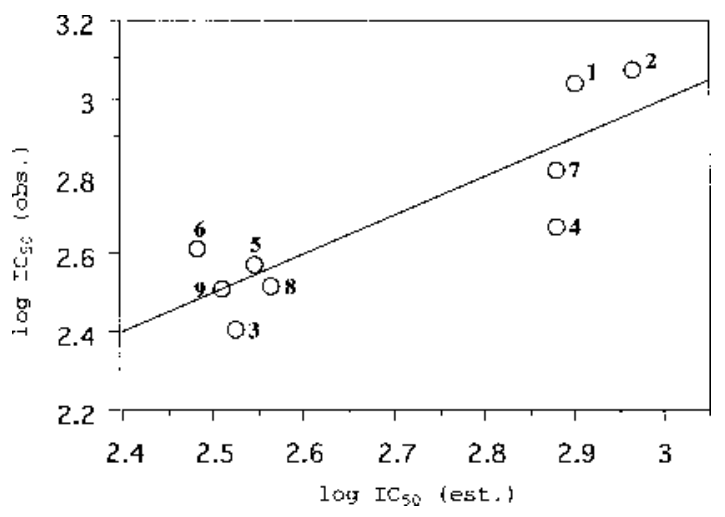

Fig. 3. Regression Plot of the Observed Values of $\log \mathrm{IC}_{50}$ and the Estimated Values Using Eq. 2

$\mathrm{C}^{10}, \mathrm{O}^{11}$, and $\mathrm{O}^{12}$ atoms. Among these electronic properties, the total energy, and solvent accessible surface area show small correlations with $\log \mathrm{IC}_{50}$. On the other hand, the charges at $\mathrm{C}^{10}$ and $\mathrm{O}^{11}$ demonstrate some definite correlations. Since the charges at the two atoms are compensated, respectively, the charge at $\mathrm{O}^{11}$ is paid an attention to the following analysis. The oxygen atom might be the biologically active site. The charges of $\mathrm{O}^{11}$ of the compounds having the hydroxyl group at the peri position of the carbonyl group adjacent to the nitrogen atom may be correlated with the enhanced inhibitory effects. As also shown in Table 3 , there is no correlation of the charge at $\mathrm{O}^{12}$ for $\log \mathrm{IC}_{50}$. Thus, we introduced the charge at $\mathrm{O}^{11}, \delta\left(\mathrm{O}^{11}\right)$, as an additional parameter, and performed a regression analysis. Then, it was found that $\log \mathrm{IC}_{50}$ can be expressed by the following equation much better than Eq. 1:

$$
\begin{gathered}
\log \mathrm{IC}_{50}=4.906+1.178 E^{\circ}+5.92 \delta\left(\mathrm{O}^{11}\right) \\
n=9, \quad s=0.203, \quad r=0.863
\end{gathered}
$$

In Fig. 3, the observed values of $\log \mathrm{IC}_{50}$ are plotted against the values estimated with this Eq. 2.

In conclusion, the standard redox potentials of azaanthraquinones determined at a physiological $\mathrm{pH}$ (7.2) and the charge at $\mathrm{O}^{11}$ are quite useful parameters for the estimation of the inhibitory effects of the azaanthraquinones on EBVEA activation.

Acknowledgements This study was supported in part by Grants-in-Aid from the Ministry of Education, Science, Sports and Culture, and the Ministry of Health and Welfare, Japan.

\section{References}

1) Konoshima T., Takasaki M., Kozuka M., Inada A., Nakanishi T., Tokuda H., Matsumoto T., Shoyakugaku Zasshi, 43, 135-141 (1989).

2) Inada A., Nakanishi T., Konoshima T., Kozuka M., Tokuda H., Nishino H., Iwashima A., Shoyakugaku Zasshi, 44, 215-218 (1990).

3) Diallo B., Vanhaelen M., Vanhaelen-Fastre R., Konoshima T., Kozuka M., Tokuda H., J. Nat. Prod., 52, 879-881 (1989).

4) Okano M., Fukamiya N., Tagahara K., Tokuda H., Iwashima A., Nishino H., Lee K. H., Cancer Lett., 94, 139-146 (1995).

5) Konoshima T., Kozuka M., Koyama J., Okatani T., Tagahara K., Tokuda H., J. Nat. Prod., 52, $987-995$ (1989).

6) Tagahara K., Koyama J., Ogura T., Konoshima T., Kozuka M., Tokuda H., Nishino H., Iwashima A., Chemistry Express, 7, 557-560 (1992).

7) Lerman L. S., J. Mol. Biol., 3, 18-30 (1961).

8) Johnson R. K., Zee-Cheng R., Cancer Treatment Reports, 63, 425439 (1979).

9) Kano K., Konse T., Nishimura N., Kubota T., Bull. Chem. Soc. Jpn., 57, 2383-2390 (1984).

10) Koyama J., Tagahara K., Osakai T., Tsujino Y., Tsurumi S., Nishino H., Tokuda H., Cancer Lett., 115, 179-183 (1997).

11) Stewart J. J. P., J. Comp. Chem., 10, 209-220 (1989).

12) Ito Y., Yanase S., Fujita J., Harayama T., Takashima M., Imanaka H., Cancer Lett., 13, 29-37 (1981).

13) Henle G., Henle W., J. Bacteriol., 91, 1248-1256 (1966).

14) Ohigashi H., Takamura H., Koshimizu K., Tokuda H., Ito Y., Cancer Lett., 30, 143-151 (1986).

15) Nicholson R. S., Shain I., Anal. Chem., 36, 706-723 (1964). 